\title{
Belgeo
}

Revue belge de géographie

$4 \mid 2005$

Miscellaneous

\section{Lebillon P. (éd.), Geopolitics of resource wars: resource dependence, governance and violence}

Numéro spécial de Geopolitics, London, Frank Cass, 2005, 277 p.

\section{Julien Vandeburie}

\section{OpenEdition}

\section{Journals}

Electronic version

URL: http://journals.openedition.org/belgeo/12228

DOI: $10.4000 /$ belgeo. 12228

ISSN: 2294-9135

\section{Publisher:}

National Committee of Geography of Belgium, Société Royale Belge de Géographie

Printed version

Date of publication: 31 December 2005

Number of pages: 521

ISSN: 1377-2368

\section{Electronic reference}

Julien Vandeburie, « Lebillon P. (éd.), Geopolitics of resource wars: resource dependence, governance and violence », Belgeo [Online], 4 | 2005, Online since 29 October 2013, connection on 22 September 2020 URL : http://journals.openedition.org/belgeo/12228; DOI : https://doi.org/10.4000/belgeo.12228

This text was automatically generated on 22 September 2020

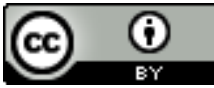

Belgeo est mis à disposition selon les termes de la licence Creative Commons Attribution 4.0 International. 


\title{
Lebillon P. (éd.), Geopolitics of resource wars: resource dependence, governance and violence
}

Numéro spécial de Geopolitics, London, Frank Cass, 2005, 277 p.

\author{
Julien Vandeburie
}

\section{REFERENCES}

Lebillon P. (éd.), Geopolitics of resource wars: resource dependence, governance and violence, Numéro spécial de Geopolitics, London, Frank Cass, 277 p.

1 This book is a special issue of Geopolitics, edited by a famous specialist of the links between conflicts and natural resources. Philippe Le Billon introduces this book with a conceptual chapter on geopolitical economy of what he calls "resource wars" where one can read a common view on this topic, sustained by good examples.

2 In a second chapter, Richard Auty develops the links between natural resources exploitation and economic difficulties. These first two chapters can be presented as the theoric part of the book. Hereafter are some case studies.

3 Michael Watts uses a specific point of view to study the effects of space governance on oil game in the Niger delta. Thad Dunning and Leslie Wirspa employ a multiscalar approach to study the links between oil and the political economy of conflict in Colombia and beyond. Unfortunately, it is too much focused on American interests.

4 Then, Philippe Le Billon and Fouad El Khatib comment the American geopolitics in the Persian Gulf, by underlying the importance of the oil dimension, from the early decades of the twentieth century to the politics of freedom oil. Sarah O'Hara uses McKinder geopolitical principles to revisit the actual great game in the Caspian sea area. Shannon O'Lear describes the stakes of the division of the Caspian sea: closed sea or simple lake? A common division or exclusive economic zone for oil and gas? 
5 Susanne Peters explains us why the «resource wars» are so important for global security, in the field of the Western energy supplies strategies. Marylin Silberfein studies the resource conflict of Sierra Leone and the role of diamonds. Finally, Kevin Dunn purposes an excellent multiscalar analysis between political economy, identity and territory in the Great Lakes area. He shows how certain economic differences (access to land, etc.) introduce identity differences, actually reused. He also shows why in this socio-economic crisis environment, warlords use discourses to legitimate the war and loot natural resources.

6 To conclude, this book offers a good introduction to the study of resource wars and shows there remains much to learn about this topic. 